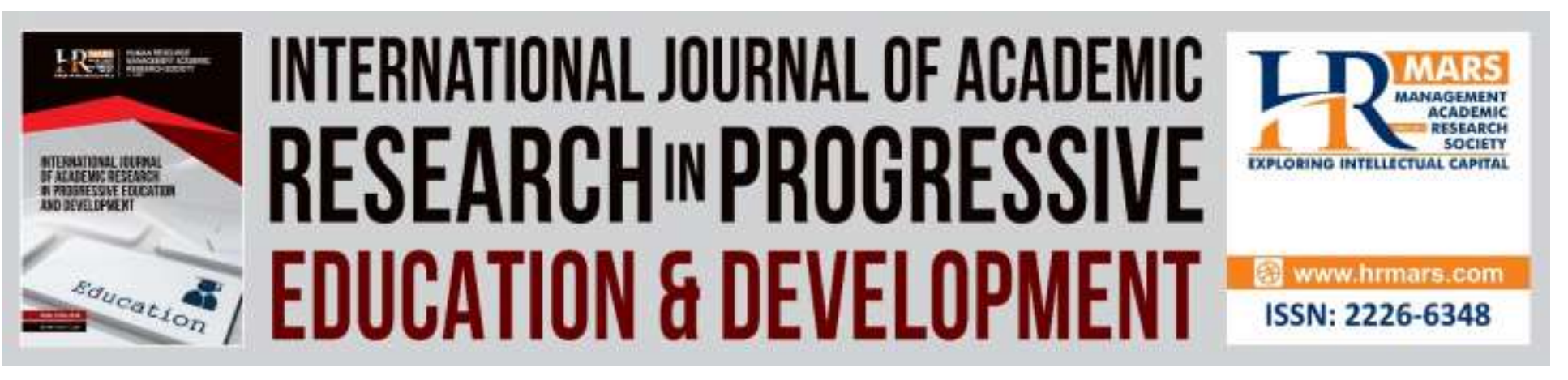

\title{
Instilling Hybrid Acting Approach to Exhibit Presentational Acting Skills of Secondary School Students through Theatre Arts Subject in Malaysian Arts School, Sungai Siput, Perak
}

Nor Shuradi Bin Haji Nor Hashim, Mohd Kipli Abdul Rahman, Lena Farida Hussain Chin

To Link this Article: http://dx.doi.org/10.6007/IJARPED/v8-i2/6122

DOI: 10.6007/IJARPED/v8-i2/6122

Received: 12 Jan 2019, Revised: 22 Feb 2019, Accepted: 01 March 2019

Published Online: 26 March 2019

In-Text Citation: (Hashim, Rahman, \& Chin, 2019)

To Cite this Article: Hashim, N. S. B. H. N., Rahman, M. K. A., \& Chin, L. F. H. (2019). Instilling Hybrid Acting Approach to Exhibit Presentational Acting Skills of Secondary School Students through Theatre Arts Subject in Malaysian Arts School, Sungai Siput, Perak. International Journal of Academic Research in Progressive and Education Development, 8(2), 449-456.

\section{Copyright: (C) 2019 The Author(s)}

Published by Human Resource Management Academic Research Society (www.hrmars.com)

This article is published under the Creative Commons Attribution (CC BY 4.0) license. Anyone may reproduce, distribute, translate and create derivative works of this article (for both commercial and non-commercial purposes), subject to full attribution to the original publication and authors. The full terms of this license may be seen

at: http://creativecommons.org/licences/by/4.0/legalcode

Vol. 8(2) 2019, Pg. 449 - 456

http://hrmars.com/index.php/pages/detail/IJARPED

JOURNAL HOMEPAGE

Full Terms \& Conditions of access and use can be found at http://hrmars.com/index.php/pages/detail/publication-ethics 


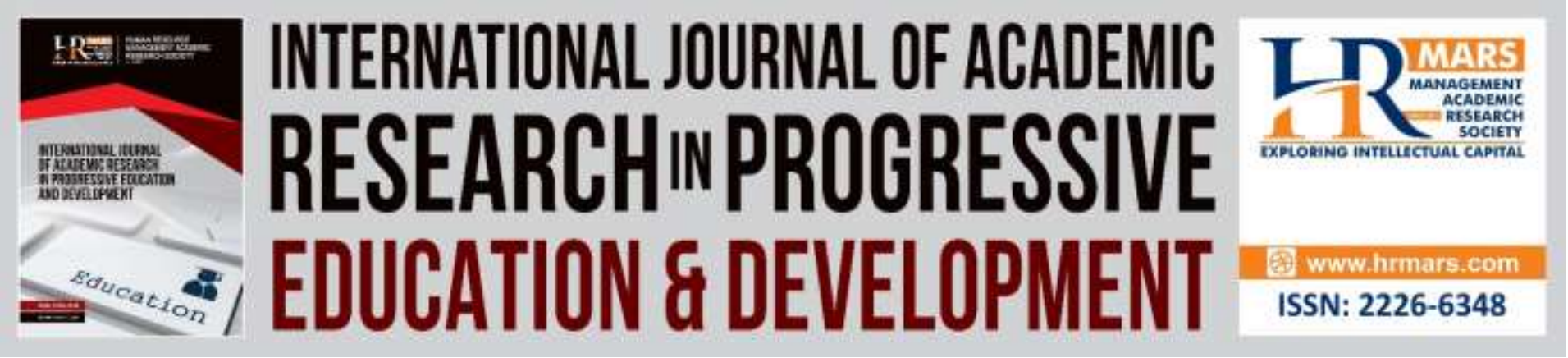

\title{
Instilling Hybrid Acting Approach to Exhibit Presentational Acting Skills of Secondary School Students through Theatre Arts Subject in Malaysian Arts School, Sungai Siput, Perak
}

\author{
Nor Shuradi Bin Haji Nor Hashim, Assoc. Prof. Dr Mohd Kipli Abdul \\ Rahman, Lena Farida Hussain Chin \\ Department of Performing Arts, Faculty of Music and Performing Arts, \\ Sultan Idris Education University, Malaysia \\ Email: shuradi@fmsp.upsi.edu.my,kipli@fmsp.upsi.edu.my, lena.farida@fmsp.upsi.edu.my
}

\begin{abstract}
In realising the teaching of acting coordinated through the Theatre Arts subject curriculum in Malaysian Arts School, Sungai Siput Perak, it is found that acting teachers and instructors have transferred improvised acting skills onto school students. However, this paper work argues about the improvisation acting skills outcome to students of Malaysian Arts School, Sungai Siput Perak who have the higher tendency to evoke realism acting effect which is entirely representational in nature. The mastery of improvisation acting skills embedded in the content of the Malaysian Arts Secondary School Standard Curriculum (KSSM) for Theatre Arts subject also opens up the opportunity for students to develop the psychomotor domain skills in developing and demonstrating the presentational acting on theatre performance free from the confinement of realism. Therefore, to develop an alternative to the form of acting that is free from realism acting, this paper work discusses the potential of the 'Hybrid Acting' concept to serve as an alternative to instil presentational acting skills among students of Malaysian Arts School in Sungai Siput Perak. We lean on the action research and the Model application by Kemmis, McTaggart \& Nixon (2013) as the study methodology. The model is coordinated to implement several phases of cycle to see the suitability of the hybrid acting approach in instilling students' skills in displaying a form of acting that is realism-free. Thus, the outcome of the action research shows that a total of 12 students were exposed to the hybrid acting skills with the ability to consolidate their respective bodies to carry out different roles by only manipulating an instrument, which is their body.
\end{abstract}

Keyword: Hybrid Acting, Presentational Acting, Realisme Acting, Hyper Reality. 
INTERNATIONAL JOURNAL OF ACADEMIC RESEARCH IN PROGRESSIVE EDUCATION AND DEVELOPMENT

Vol. 8, No. 2, 2019, E-ISSN: 2226-6348 @ 2019 HRMARS

\section{Introduction}

In experiencing the post-modernism culture that is laden with the technology and sophisticated digital media, Baudrillard (2007) has coined the real world is gathered, filtered and improved to become a sign that transcends the reality and manifests itself as the hyper-reality. In hyper-reality all the markers that direct towards the representation of the reality have been dropped down. Subsequently, the sign of reality mingles with the artificial and non-genuine signifiers. It gets to a point when this mixture of reality references and non-reality references embedded in a piece of art work can no longer be differentiated or determined easily. Thus, in the context of theatrical performance that follows the post-modernism art mode, it also builds its own tendency as a simulation that drives towards the markers that violate the representation of the reality. Indeed, Pavis (2013) asserts that the form of theatrical performance today has also shifted to the antirealism theatre style in a way that it no longer imitates the setting and object of the performance that closely refers to the real world. By contrast, the stage setting, the lighting composition, the costume, the props and other aesthetic requirements no longer lean towards the truth or what is real. Reversibly, this creates a crisis of the real representation in art as it is seen as more superficial and able to create itself as hyper reality. Related to this, the acting style in the hyper reality world is also manipulated by actors to create an acting impact that no longer focuses on realistic and representational acting order. According to Schechner (2013), realistic acting is an everyday human behavior. It means that realistic acting carried by the actors on stage represents humans' everyday behavior and actions identifiable as the real world that is experienced, gone through or known by the audience. This is different from the presentational acting that intends to go in contradiction of the realism acting by prioritizing more on the body as a symbol of the narrative. In this vein, the presentational form of acting can be observed through the physical theater genre that ses acting resources such as mime, pantomime, corporeal mime, creative movements, dance-drama and any kind of acting that receives the Brechtian influence.

In the context of the teaching of stage acting skills, the Malaysian Arts Secondary School Standard Curriculum (KSSM) also introduces various approaches and methods of acting to students who enrol in theatre arts studies, especially those from Malaysian Arts Secondary School, Sungai Siput Perak. Guided by KSSM's Theatre Arts subject for Form 1, Form 2 and Form 3 topics that expose students to the representational acting skills (realism) and presentational (anti-realism) acting skills have been developed. In line with this, an action research was done by the researcher to instil students' creativity in demonstrating the presentational acting that concentrates on the hybrid acting style. Based on the participation of 12 students of Malaysian Arts Secondary School Sungai Siput, Perak as the instrument of the study, this action research is done to instill the students' psychomotor skills of Malaysian Arts Secondary School Sungai Siput, Perak using hybrid acting. As the effect to the acting skills using the hybrid acting skills, it can become an alternative in helping students to generate their psychomotor domain in the form of presentational form of acting.

\section{Problem Statement}

In comprehending the teaching of acting skills coordinated through Theatre Arts subject curriculum for students of Form 1,2 and 3 in the Malaysian Arts Secondary School, Sungai Siput Perak it has 
shown teachers' and instructors initiatives in exposing students to the improvisation technique as knowledge of stage acting skills. However, through the pilot study conducted to examine the skills of Form 1, Form 2 and Form 3 in Malaysian Arts Secondary School, Sungai Siput Perak, manipulating their bodies to reveal acting form using an improvised acting technique. Thus, the improvised acting skills applied to the students have been found to have the tendency to act out realism and representational forms of acting in performance tasks. As a matter of fact, the improvisation technique embedded in Malaysian Arts Secondary School Standard Curriculum (KSSM) for Theatre Arts subject for Form 1, Form 2 and Form 3 have the potential to develop their psychomotor skills by developing and demonstrating presentational form of acting on a genre that is permitted from the restrictions set by realism. Thus, this paper work questions about students' opportunity to develop their psychomotor skills in demonstrating the presentational form of acting. This contradicts the development of the theatre performance that is unrestricted from the aesthetic value that is characteristically hyper-real and anti-structural. With this, this paper work talks about the students' psychomotor skills - those in Form 1 to 3 who follow the Theatre Arts subjects in the Malaysian Arts Secondary School in Sungai Siput Perak who also have to achieve the presentational form of acting. This is important to prepare and develop the students' psychomotor domain so that they are able to do a creative process when they are acting on stage, something that violates the boundaries of the realism theatre. Thus, this paper talks about the 'Hybrid Acting' applied as an alternative approach. According to Schechner (2017), 'Hybrid Acting' is a concept of acting that countenances an actor to represent various characters' backgrounds emerging from various sociological, psychological and physiological backgrounds in one specific performance space. Using 'Hybrid Acting', an actor has the potential to break apart realistic acting by allowing his or her body as an instrument to act as a sign that transcends realistic facts. This is made possible through the use of hybrid acting. The effect of this allows an actor to change their body symbol in an extreme way by playing a role as a character and transforms into another without having to have another actor to play in an ensemble. Thus, hybrid acting can serve as an alternative approach to encourage students to strengthen their psychomotor skills in displaying acting that is free of realism order. Thus, the hybrid acting approach in the process of teaching acting skills coordinated through this action research can serve as guidance to teachers and instructors to generate a form of alternative form of acting to diversify students' skills in stage acting.

\section{Study/Objective}

This study aims to identify the teaching of the 'Hybrid Acting' technique as a strategy in instilling the skills of presentational acting among students who follow the Theater Arts subject in the Malaysian Arts Secondary School, Perak. On this note, an action research has been developed to prove the study objective (1) The teaching and learning that uses the Hybrid Acting get to instill the students' psychomotor skills through role-playing activity. (2) the teaching and learning using 'Hybrid Acting' get to instill students' acting skill through the presentational acting. Therefore, to realize objective (1), this study encourages students to adopt the 'Hybrid Acting' in their acting via role-playing. To realize objective (2), this study seeks to identify the extent of the approach in instilling students' psychomotor skills in building presentational acting. This is tested by applying the role-playing method to make sure that the 'hybrid acting' can be applied by individual students in this particular school. 
INTERNATIONAL JOURNAL OF ACADEMIC RESEARCH IN PROGRESSIVE EDUCATION AND DEVELOPMENT

Vol. 8, No. 2, 2019, E-ISSN: 2226-6348 @ 2019 HRMARS

\section{Importance/Benefit}

The outcome of this action research is expected to benefit the students of the Malaysian Arts Secondary School in Perak where it can help them build and display their acting skills using the 'hybrid acting' technique. This is important to ensure that the vision of the Malaysian Education Development Plan (PPPM) 2015-2025 can be realised by producing students who have the 4C skills namely communication, creativity, critics and collaborative. It is also in support of the aim of PPPM 2015-2025 in producing students who have a sense of curiosity and who can apply knowledge to solve their real-life issues.

\section{Study Methodology}

This study aims to provide learning on Hybrid Acting Techniques as a strategy to nurture acting skills among students at Malaysian Arts School, Sungai Siput, Perak. The objective of this study was to develop psychomotor domain skills among students through the development of presentational acting using hybrid acting. To improve the quality of teaching and learning of presentational acting in the classroom. Thus the methodology of the study has used the model of Kemmis, McTaggart \& Nixon (2013) because the hybrid acting approach needs to be implemented in several phases to see the effectiveness and appropriateness of this approach applied in achieving student learning goals in developing presentational acting skills. The design of this research has shown the cycles in the Action Research whereby every cycle has 4 parts, namely (1) planning (2) action (3) observation (4) reflection. These parts will then be repeated with the outcome of the test and the subsequent actions.

\section{Diagram 1: Cycle 1 - Action Research Implementation Research's Revision through Kemmis, McTaggart \& Nixon (2013)}

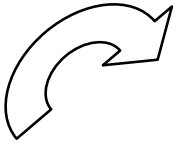

(3) Observation

Doing the Role Play and Spontaneous Acting to identify students' skills in organizing their body to change the symbol of the roles they play. Then they are able to reorganize the body symbol to demonstrate another role.

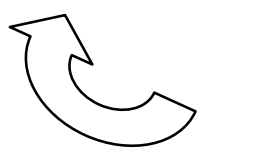

(4) Reflection

If students are still weak at displaying 'hybrid acting' skills, repetitious training plan is done to strengthen the presentational acting skills.

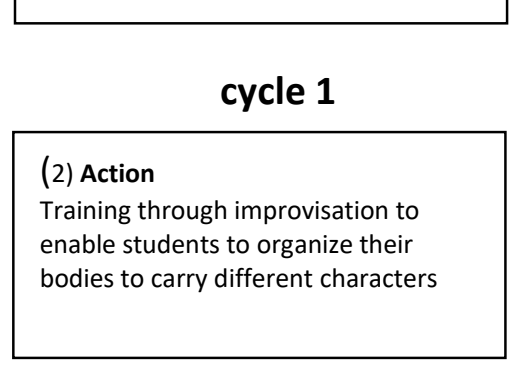

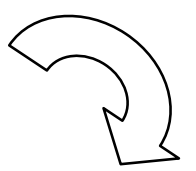

(1) Planning The use of the 'hybrid acting' concept to build actions in a presentational way.

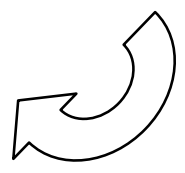

Diagram 2: Cycle 2 - Action Research Implementation Research's Revision Through Kemmis \& McTaggart \& Nixon Model (2013) 


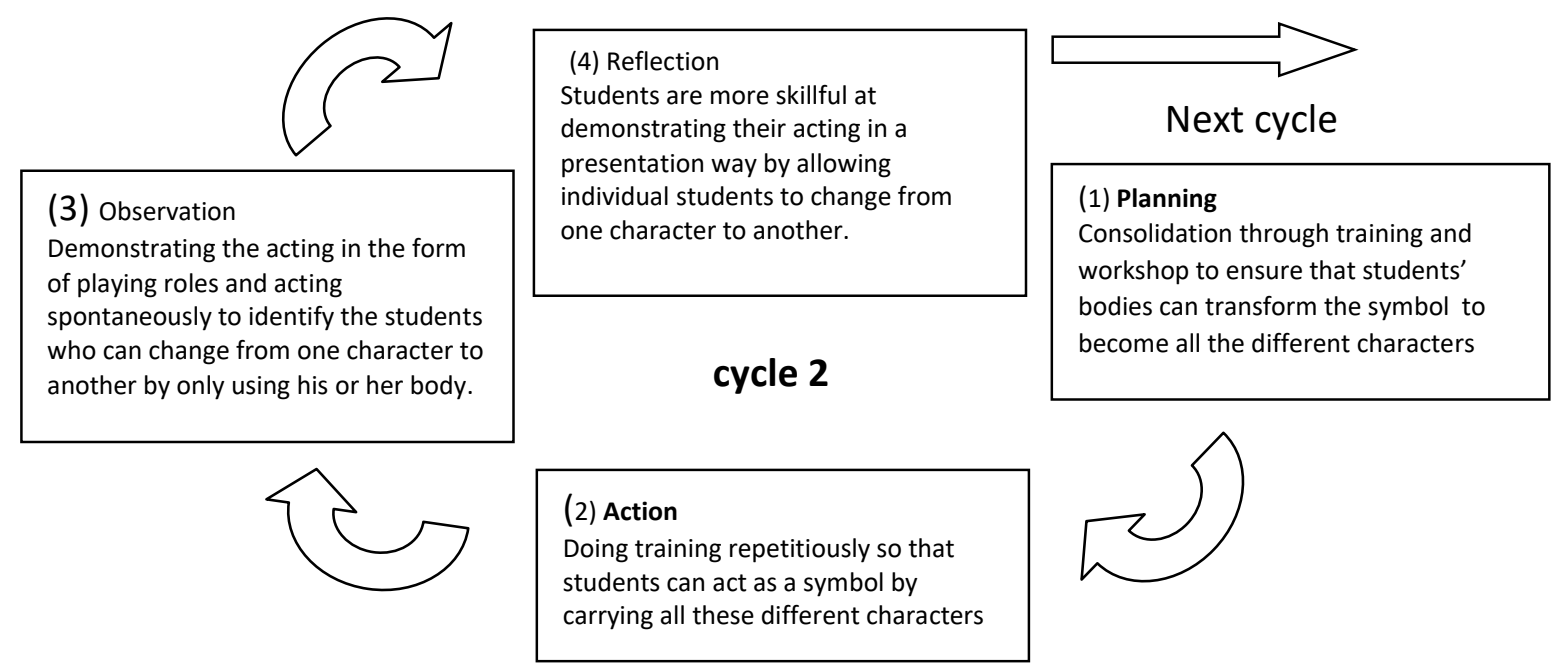

\section{Study Finding}

Based on the analysis of the study objective and the action research methodology applied in this study, it has proven that the 'hybrid acting' approach is able to instill the students' psychomotor skills where they get to demonstrate a form of acting that is free from realism. Inclined on the action research done in the classroom together with 12 students at the same time practicing the 'hybrid acting' approach as another alternative to help students expand their skills in acting that is free from realism which is characteristically representational. The outcome finds that 12 students have been able to manipulate their body symbol to play various characters- as a materialistic father, as a temperamental old man, as a mad woman, as a mother who suffers the humiliation from her own child, a gangster, an angry young lady, a neighbor who likes to gossip, a fierce school teacher and a happy go lucky child, a woman with issues, a thief and a drug addict- all carried out spontaneously. This is all successfully done using the 'Hybrid Acting' approach.

Other than spontaneous acting, this action research also tests students' skills in doing 'hybrid acting' by suggesting that the participants of study act out a theatrical performance that emerges from the local dramatists' anti-realism scripts. Also, this action research uses the script entitled 'Tepuk Amai-Amai' written by dramatist Wan Khairunazwan Rody. 'Tepuk Amai-Amai' revolves around the conflict of three girls or students named Dira, Nadirah, Nana and three male students named Topex, Aloy and Afiq who have to face some obstacles as they finish their school term. Thus, the conflict depicted in the story 'Tepuk Amai-Amai' requires 12 students to play the roles of students, parents, teachers, family members and reporters by only using 3 males and 3 females. Thus, by having the groups divided into two, the assessment on the action research requires 3 male students and 3 female students to pay the roles as students, teachers, reporters, parents and family members by only manipulating the individual bodies. Following the activities of planning, action, observation and reflection it is found that the action research has been able to instill the psychomotor domain skills for 12 students of the Malaysian Arts Secondary School in Sungai Siput Perak in exhibiting the lives of school students, teachers, reporters, parents and family members in the 'hybrid acting' form. Indeed, the 'hybrid acting' approach allows students to 


\section{INTERNATIONAL JOURNAL OF ACADEMIC RESEARCH IN PROGRESSIVE EDUCATION AND DEVELOPMENT}

Vol. 8, No. 2, 2019, E-ISSN: 2226-6348 @ 2019 HRMARS

manipulate his or her own body symbol by playing the role as school students. Thus, the process of manifesting the characters in the play Tepuk Amai-Amai continues by allowing the students to have pay other roles, like mother, father, family members, teachers and reporters. Next, students continue to perform 'hybrid acting' by again, allowing their body to change into the different roles.

In short, the spontaneous acting or the role-playing activity can serve as the action research activity to help 12 students instil their skills in displaying the behaviour of characters using the 'hybrid acting' approach. This is done by getting students to organise their individual body in changing the role symbol of school student. Thus, the theatrical performance continues by allowing students to change the symbol into the characters of parents and family members, school educators, journalists or reporters and a Minister until the tasks and cycles in the action research have reached their objectives.
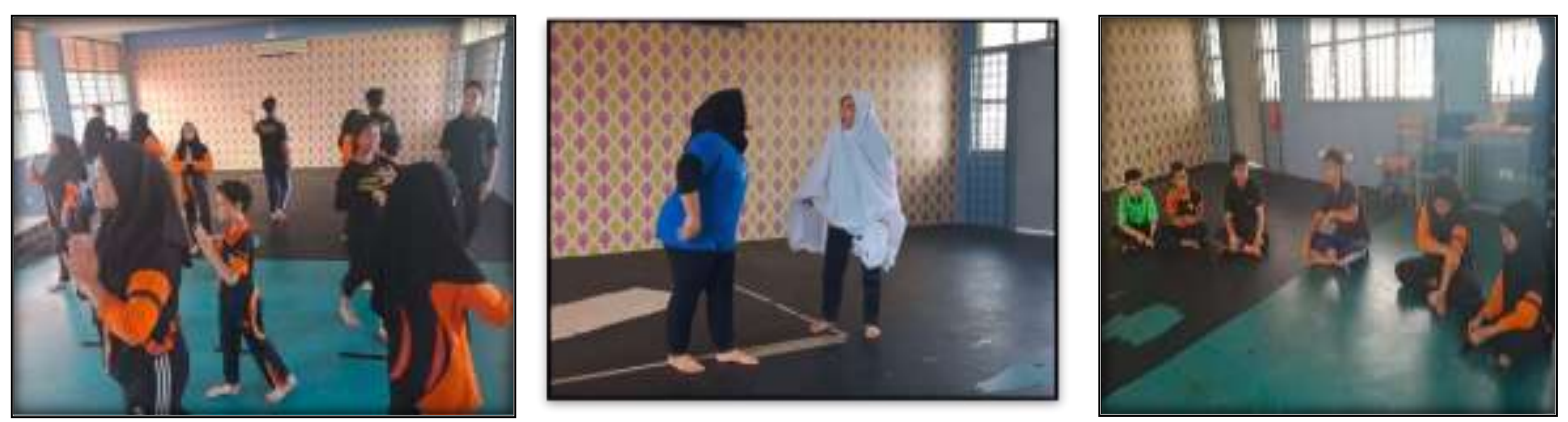

Figure 1: Roles-plays activities with the students to develop presentational acting style using 'hybrid acting' skills.

\section{Conclusion of the Study Outcome}

This study argues that the 'hybrid acting' approach is able to instill the skills 12 students from the Malaysian Arts Secondary School in Perak where they get to develop and demonstration presentational acting. It shows that 'hybrid acting' can serve as an alternative in instilling Malaysian Arts Secondary School students' acting skills, by manipulating their individual bodies signifier from being a character to another character. Thus, the outcome of the action research has been able to prove that the 'hybrid acting' approach is able to instill the students' acting skills in developing and demonstration a form of presentational acting that deviates from the boundaries of realism as hyper reality condition.

\section{Acknowledgement}

This research is funded by University Research Grant (GPU) - (2018-0017-107-01) University Research Grant (GPU) from Universiti Pendidikan Sultan Idris.

\section{Corresponding Author}

Mr. Nor Shuradi Nor Hashim Department of Performing Arts Faculty of Music and Performing Arts Universiti Pendidikan Sultan Idris Perak Malaysia

Email: shuradi@fmsp.upsi.edu.my 
INTERNATIONAL JOURNAL OF ACADEMIC RESEARCH IN PROGRESSIVE EDUCATION AND DEVELOPMENT

Vol. 8, No. 2, 2019, E-ISSN: 2226-6348 @ 2019 HRMARS

\section{Reference}

Baudrillard, J. (2007). Symbolic Exchanged and Death. (L. Hamilton, Trans.). New York, NY:Sage.

Kemmis, S., McTaggart, R., Nixon, R. (2013). The Action Research Planner: Doing Critical Participatory Action Research. Australia: Springer.

Pavis, P. (2013). Contemporary Mise-En-Scene: Staging Theatre Today.(Anderson, J. Trans).London. UK: Routlegde.

Schechner, R. (2013). Performances Studies: An Introduction. (Third Edition).London.UK: Routledge. 